\title{
Knowledge and Perceptions of HIV/AIDS among High School Students in Jeddah, Saudi Arabia
}

Ssakher M Alotaibi" ${ }^{*}$, Faisal F Alabbas ${ }^{2}$, Abdullah F Almoshadq ${ }^{1}$, Majed S Pacha ${ }^{3}$ and Mohammed K Alghamdi ${ }^{4}$

${ }^{1}$ Medical Resident at King Abdullah Medical City, Saudi Arabia

${ }^{2}$ Pediatric Demonstrator at King Abdulaziz University Hospital, Saudi Arabia

${ }^{3}$ Medical Resident at King Fahd Armed Forces Hospital, Saudi Arabia

${ }^{4}$ King Abdulaziz University, Saudi Arabia

\begin{abstract}
The Middle East and North Africa (MENA) region has the world's third fastest growing AIDS epidemic, but data on HIVIAIDS from this region is considered scarce. In this study, we report a cross-sectional survey of knowledge of and attitudes to HIV and AIDS among 438 high school students in Jeddah, Saudi Arabia. This city is an international gateway with the highest HIV incidence in the country. The survey highlights both good awareness of HIV with regard to transmission by sexual contact and injection, and also deficiencies in knowledge about other routes of transmission. The data indicate substantial stigma associated with HIVIAIDS patients, consistent with other reports from the MENA region. These outcomes highlight a need for greater education on at least some aspects of HIV; they also provide a benchmark for future research and a basis for discussions of public policy towards HIVIAIDS awareness and education in Saudi Arabia.
\end{abstract}

Keywords: Attitudes; Awareness; Cross-sectional survey; Education; High school students; HIV; Knowledge; Jeddah; Saudi Arabia

\section{Introduction}

In 2014, 34.3 million people were infected with HIV, including 17.4 million women and 2.6 million children [1]. There were 1.8 million new cases and 1.0 million deaths. The World Health Organization Middle East and North Africa (MENA) region has the third fastest growing AIDS epidemic [2]

In the Kingdom of Saudi Arabia (KSA), the total number of HIV cases from 1984-2013 was estimated to be about 20,500 [3]. In 2013, 1777 cases were newly diagnosed, $79 \%$ of them aged $15-49$ years [4]. Up to the end of 2012, HIV cases in KSA included 5,348 Saudis and 13,414 foreigners. According to a report released by the Saudi Ministry of Health, $96 \%$ percent of patients became HIV-positive through sexual intercourse, $2.5 \%$ through injection, and $1.5 \%$ by infection during pregnancy. More than 600 Saudi women were infected postmarriage and about $80 \%$ of infected women acquired the disease from their husbands [3]. The CIA World Fact book reports an overall HIV prevalence of $<0.1 \%$ in the country, with 300 deaths annually [5].

Various factors are relevant to understanding risk, prevalence and knowledge of HIV/AIDS in KSA. Saudi Arabia is a conservative Islamic society. There is a lack of public health education and in-school education on matters related to HIV/AIDS. It may be taboo to discuss risk factors such as sexual practices and injected drug use. There may be gender-related differences in knowledge. In such circumstances, it is important to assess knowledge and understanding of HIV and AIDS among the young population as this group is crucial to preventing the spread of the disease [6]; 15-24 year old's account for $40 \%-50 \%$ of new cases globally [7]. It is also relevant to establish attitudes of the population to those infected with HIV/AIDS.

In this study, we report a cross-sectional survey of knowledge about and attitudes to HIV/AIDS among high school students in the city of Jeddah, KSA. Jeddah, population 3.4 million, is the second largest city in the country and a major port on the Red Sea; it is the major urban center of western Saudi Arabia. Jeddah is also a resort city and the principal gateway to Mecca, Islam's holiest city, which able-bodied Muslims are required to visit in pilgrimage at least once in their lifetime. Forty percent of reported HIV cases in KSA are in Jeddah [8]. This relatively high prevalence compared to the rest of the country is believed to be due to the presence of a large number of expats, especially Africans [3]. Immigration from low-income/high-risk countries increases the risk of disease spread to the local population.

Data from the MENA region that is available includes a crosssectional study undertaken in high schools in Erbil City, Iraq, in 2014, which assessed knowledge of HIV/AIDS against socioeconomic factors [9]. There was also a survey of 5000 illegal residents of KSA (published in 2015), around 40\% (two thousand) of whom were living in Jeddah [10]. Knowledge of HIV transmission was poor in $90 \%$ of respondents, which represents at least a theoretical risk to those surveyed in the present work. A very brief report published in 2015 [11] surveyed adolescents (aged 16-19) in shopping malls in the Eastern Province of Saudi Arabia. Beyond this, data from Yemen [12] and KSA [13] are at least 10 years old and thus their continued relevance is unclear.

\section{Aims of this Study}

To survey knowledge of and attitudes to HIV and AIDS among high school students in the city of Jeddah, Saudi Arabia. Further, to assess the outcomes of the survey by demographic characteristics and the implications of the data for HIV/AIDS awareness and education.

\section{Methods}

\section{Study design}

A cross-sectional study was conducted among high school students in Jeddah, Saudi Arabia. Thirty-two questions were asked, divided into

*Corresponding author: Ssakher AlOtaibi, Medical Resident at King Abdullah Medical City, Saudi Arabia, Tel: 00966554643222; E-mail: dr.sakher10@gmail.com

Received June 09, 2016; Accepted June 25, 2016; Published July 02, 2016

Citation: Alotaibi SM, Alabbas FF, Almoshadq AF, Pacha MS, Alghamdi MK (2016) Knowledge and Perceptions of HIVIAIDS among High School Students in Jeddah, Saudi Arabia. J AIDS Clin Res 7: 595. doi:10.4172/2155-6113.1000595

Copyright: (c) 2016 Alotaibi SM, et al. This is an open-access article distributed under the terms of the Creative Commons Attribution License, which permits unrestricted use, distribution, and reproduction in any medium, provided the original author and source are credited. 
four categories: Questions concerning routes of transmission of HIV; general knowledge about HIV/AIDS; questions about preventative measures; and attitudes toward infected patients.

\section{Sample characteristics}

A total of 438 high school students were surveyed. Summary demographic information concerning the participants is given in Tables in the Supplementary material. The students were divided according to their location of residence between north Jeddah $(n=168)$ and south Jeddah $(n=270)$. Schools $(n=8)$ were selected at random and students were randomly selected from within their schools. People from the north of Jeddah have a higher mean family income than people from the south. Students in the north group are considerably more likely to be receiving private (rather than governmental) education than those in the south group. On average, both parents of students in the north group had a higher level of education than parents of students in the south group. The mean age of the students surveyed in the groups was $15 \pm 19$ years (north) and $15 \pm 19$ years (south) (age range 15-26 years; $82 \%$ aged $15-19$ years) and there was no statistically significant difference in age between the groups. Notably, there was no significant difference between the groups in the employment of the students' parents in medical work.

The response rate to the survey was $54.7 \%$. The questionnaire was designed by Infectious Control Consultant at King Abdulaziz University Hospital and reviewed by Infectious Disease Consultant at King Abdulaziz University Hospital]. It was translated into Arabic, the language used in the schools, by an infectious disease control consultant, and retranslated by a native Arabic speaker; the English versions were compared and found to avoid mismatch. The survey was conducted from $30^{\text {th }}$ August 2014 to $14^{\text {th }}$ January 2015. Surveys were completed by individual students without communicating with others present.

\section{Statistical analysis}

Statistical analysis was performed using the Statistical Package for the Social Sciences software. Chi-square tests were used to compare data. Differences were considered statistically significant at $\mathrm{P}<0.05$.

\section{Statement on ethics}

This study was approved by the Biomedical Ethics Committee at King Abdulaziz University Hospital. The purpose of the study was explained to all participants and informed consent was obtained verbally from both the participating students and their parents. Surveys were conducted anonymously and participants were assured of the confidentiality of their responses. Students were free to decline to participate in the survey.

\section{Results}

\section{Routes of transmission of HIV}

Table 1 shows the questions concerning routes of transmission of HIV and the responses obtained from the 438 students surveyed in Jeddah. Reponses are subdivided into "north" and "south" according to the region of the city in which the student resided. Relative to the south, students in the north group had, on average, a higher level of family income, and both of their parents had a higher level of education (Supplementary Tables).

More than $93 \%$ of respondents considered that sexual contact is a route of transmission of HIV, with no significant difference between the north and south groups. Regarding transmission by oral sex, $74.4 \%$ of the south group considered this a route of transmission, whereas this figure was $62.5 \%$ among the north group. There was a significant difference between the south and north groups concerning transmission by kissing: $60.9 \%$ from the south considered this a route of transmission, while the corresponding figure was only $43.5 \%$ among the north group. More than $23 \%$ of respondents in the south believed that shaking hands is a means of HIV transmission, and the corresponding figure was $32.7 \%$ in the north (26.9\% overall). No significant differences were observed between the groups regarding shaving (sharing of razors) as a route of transmission; a total of $81.1 \%$ were aware of this route, while $90.8 \%$ (south) and $83.9 \%$ (north) were aware of sharing of needles as a transmission route.

No significant difference was observed in the response from the two groups concerning whether pregnancy is a means of HIV transmission (south $74.9 \%$; north $67.9 \%$ ). Half of both groups considered mosquito bites a means of transmission. There was a significant difference between the two groups concerning the use of public bathrooms: $53.1 \%$ of those in the south and $32.7 \%$ of those in the north regarded this as a transmission route. Sharing food with an infected person was considered a transmission route by $32.8 \%$ of the southern group and $22.0 \%$ of the northern respondents.

\section{General knowledge about HIV/AIDS}

Table 2 reports general knowledge about HIV/AIDS among the students surveyed. A large majority (78.6\%) answered that HIV is a viral infection (rather than bacterial), without a significant difference between the north and south groups. Of the total, $49.2 \%$ thought that there is a vaccine against HIV (54.2\% south, $41.1 \%$ north). Meanwhile, $81.3 \%$ of the total survey responded that there is no definitive treatment for HIV, without a significant difference between the groups. Regarding the existence of medications to prevent viral proliferation, $41.3 \%$ of the south group and $36.3 \%$ of the north group were not aware of these; $55.7 \%$ (south) and $64.3 \%$ (north) of respondents believed that there are medications to decrease the incidence of transmission from a pregnant woman to her fetus. Roughly half of the respondents in both groups considered AIDS to be common in Jeddah. Meanwhile, $37.8 \%$ answered that sexual contact is the only way for transmission, without a significant difference between the north and south groups; this result is perhaps surprising in light of the data (Table 1) concerning knowledge about sharing of needles and razors as a route of transmission.

\section{Means to prevent HIV}

Table 3 shows responses of the surveyed students to questions about means to prevent HIV/AIDS. There was no significant difference between the north and south groups in terms of considering the use of condoms (77.8\% of the total) and sterilizing needles (82.6\%) as means of reducing transmission. Similarly, both groups recognized the value of routine checkups ( $87 \%$ overall), without a significant difference between them. There was, however, a significant difference between the groups in considering whether isolation of infected people is a way to reduce the spread of the virus: $74.2 \%$ agreed in the south, but only $58.3 \%$ in the north. Around 56\% of both groups answered that avoiding eating with an infected person is a way to reduce transmission of HIV, while $60.8 \%$ of the total number thought that avoiding using public bathrooms is way to reduce the spread of the virus, with a significant difference between south (65.7\%) and north (53.0\%).

\section{Attitudes to HIV/AIDS patients}

Table 4 shows data concerning attitudes toward infected patients. Overall, $61.5 \%$ of our survey participants would feel shy to ask an HIV patient about the mode of their infection. Approximately $23 \%$ of 
Citation: Alotaibi SM, Alabbas FF, Almoshadq AF, Pacha MS, Alghamdi MK (2016) Knowledge and Perceptions of HIVIAIDS among High School Students in Jeddah, Saudi Arabia. J AIDS Clin Res 7: 595. doi:10.4172/2155-6113.1000595

Page 3 of 7

\begin{tabular}{|c|c|c|c|c|c|}
\hline QUESTION & ANSWER & & SOUTH & NORTH & TOTAL \\
\hline \multirow{4}{*}{$\begin{array}{l}\text { Is sexual contact considered a route of } \\
\text { transmission? }\end{array}$} & \multirow{2}{*}{ Yes } & Count & 252 & 158 & 410 \\
\hline & & $\%$ within group & $93.3 \%$ & $94.0 \%$ & $93.6 \%$ \\
\hline & \multirow{2}{*}{ No } & Count & 18 & 10 & 28 \\
\hline & & $\%$ within group & $6.7 \%$ & $6.0 \%$ & $6.4 \%$ \\
\hline \multirow{2}{*}{\multicolumn{2}{|c|}{ Total }} & Count & 270 & 168 & 438 \\
\hline & & $\%$ within group & $100 \%$ & $100 \%$ & $100 \%$ \\
\hline \multirow{4}{*}{$\begin{array}{l}\text { Is oral sex considered a route of } \\
\text { transmission? }\end{array}$} & \multirow{2}{*}{ Yes } & Count & 201 & 105 & 306 \\
\hline & & $\%$ within group & $74.4 \%$ & $62.5 \%$ & $69.9 \%$ \\
\hline & \multirow{2}{*}{ No } & Count & 69 & 63 & 132 \\
\hline & & $\%$ within group & $25.6 \%$ & $37.5 \%$ & $30.1 \%$ \\
\hline \multirow{2}{*}{\multicolumn{2}{|c|}{ Total }} & Count & 270 & 168 & 438 \\
\hline & & $\%$ within group & $100 \%$ & $100 \%$ & $100 \%$ \\
\hline \multirow{4}{*}{$\begin{array}{l}\text { Is kissing considered a route of } \\
\text { transmission? }\end{array}$} & \multirow{2}{*}{ Yes } & Count & 165 & 73 & 238 \\
\hline & & $\%$ within group & $60.9 \%$ & $43.5 \%$ & $54.2 \%$ \\
\hline & \multirow{2}{*}{ No } & Count & 106 & 95 & 201 \\
\hline & & $\%$ within group & $39.1 \%$ & $56.5 \%$ & $45.8 \%$ \\
\hline \multirow{2}{*}{\multicolumn{2}{|c|}{ Total }} & Count & 271 & 168 & 439 \\
\hline & & $\%$ within group & $100 \%$ & $100 \%$ & $100 \%$ \\
\hline \multirow{4}{*}{$\begin{array}{l}\text { Is shaking hands considered a route of } \\
\text { transmission? }\end{array}$} & \multirow{2}{*}{ Yes } & Count & 63 & 55 & 118 \\
\hline & & $\%$ within group & $23.2 \%$ & $32.7 \%$ & $26.9 \%$ \\
\hline & \multirow{2}{*}{ No } & Count & 208 & 113 & 321 \\
\hline & & $\%$ within group & $76.8 \%$ & $67.3 \%$ & $73.1 \%$ \\
\hline \multirow{2}{*}{\multicolumn{2}{|c|}{ Total }} & Count & 271 & 168 & 439 \\
\hline & & $\%$ within group & $100 \%$ & $100 \%$ & $100 \%$ \\
\hline & Yoc & Count & 226 & 130 & 356 \\
\hline Is shaving considered a route of & res & $\%$ within group & $83.4 \%$ & $77.4 \%$ & $81.1 \%$ \\
\hline transmission? & $\mathrm{Nh}$ & Count & 45 & 38 & 83 \\
\hline & 100 & $\%$ within group & $16.6 \%$ & $22.6 \%$ & $18.9 \%$ \\
\hline Total & & Count & 271 & 168 & 439 \\
\hline Tulal & & $\%$ within group & $100 \%$ & $100 \%$ & $100 \%$ \\
\hline & Yes & Count & 246 & 141 & 387 \\
\hline Is sharing needles considered a route of & 100 & $\%$ within group & $90.8 \%$ & $83.9 \%$ & $88.2 \%$ \\
\hline transmission? & $\mathrm{Ne}$ & Count & 25 & 27 & 52 \\
\hline & 100 & $\%$ within group & $9.2 \%$ & $16.1 \%$ & $11.8 \%$ \\
\hline Total & & Count & 271 & 168 & 439 \\
\hline Tolal & & $\%$ within group & $100 \%$ & $100 \%$ & $100 \%$ \\
\hline & Yec & Count & 203 & 114 & 317 \\
\hline Is pregnancy considered a route of & Yes & $\%$ within group & $74.9 \%$ & $67.9 \%$ & $72.2 \%$ \\
\hline transmission? & $\mathrm{Nh}$ & Count & 68 & 54 & 122 \\
\hline & INO & $\%$ within group & $25.1 \%$ & $32.1 \%$ & $27.8 \%$ \\
\hline Total & & Count & 271 & 168 & 439 \\
\hline Tulal & & $\%$ within group & $100 \%$ & $100 \%$ & $100 \%$ \\
\hline & Yes & Count & 137 & 82 & 219 \\
\hline Are mosquito bites considered a route of & 100 & $\%$ within group & $50.6 \%$ & $48.8 \%$ & $49.9 \%$ \\
\hline transmission? & No & Count & 134 & 86 & 220 \\
\hline & INO & $\%$ within group & $49.4 \%$ & $51.2 \%$ & $50.1 \%$ \\
\hline Total & & Count & 271 & 168 & 439 \\
\hline Tulal & & $\%$ within group & $100 \%$ & $100 \%$ & $100 \%$ \\
\hline & & Count & 144 & 55 & 199 \\
\hline Is using public bathrooms considered a route & Yes & $\%$ within group & $53.1 \%$ & $32.7 \%$ & $45.3 \%$ \\
\hline of transmission? & $\mathrm{Ne}$ & Count & 127 & 113 & 240 \\
\hline & NO & $\%$ within group & $46.9 \%$ & $67.3 \%$ & $54.7 \%$ \\
\hline & & Count & 271 & 168 & 439 \\
\hline Iotal & & $\%$ within group & $100 \%$ & $100 \%$ & $100 \%$ \\
\hline & Yes & Count & 134 & 58 & 192 \\
\hline Is breast feeding considered a route of & res & $\%$ within group & $49.6 \%$ & $34.5 \%$ & $43.8 \%$ \\
\hline transmission? & $\mathrm{No}$ & Count & 136 & 110 & 246 \\
\hline & INO & $\%$ within group & $50.4 \%$ & $65.5 \%$ & $56.2 \%$ \\
\hline Total & & Count & 270 & 168 & 438 \\
\hline Tolal & & $\%$ within group & $100 \%$ & $100 \%$ & $100 \%$ \\
\hline
\end{tabular}


Citation: Alotaibi SM, Alabbas FF, Almoshadq AF, Pacha MS, Alghamdi MK (2016) Knowledge and Perceptions of HIVIAIDS among High School Students in Jeddah, Saudi Arabia. J AIDS Clin Res 7: 595. doi:10.4172/2155-6113.1000595

Page 4 of 7

\begin{tabular}{|c|c|c|c|c|c|}
\hline \multirow{4}{*}{$\begin{array}{l}\text { Is sharing food with infected people } \\
\text { considered a route of transmission? }\end{array}$} & \multirow{2}{*}{ Yes } & Count & 89 & 37 & 126 \\
\hline & & $\%$ within group & $32.8 \%$ & $22.0 \%$ & $28.7 \%$ \\
\hline & \multirow{2}{*}{ No } & Count & 182 & 131 & 313 \\
\hline & & $\%$ within group & $67.2 \%$ & $78.0 \%$ & $71.3 \%$ \\
\hline \multirow{2}{*}{\multicolumn{2}{|c|}{ Total }} & Count & 271 & 168 & 439 \\
\hline & & $\%$ within group & $100 \%$ & $100 \%$ & $100 \%$ \\
\hline
\end{tabular}

Table 1: Questions concerning routes of transmission of HIV.

\begin{tabular}{|c|c|c|c|c|c|}
\hline QUESTION & ANSWER & & SOUTH & NORTH & TOTAL \\
\hline \multirow{4}{*}{ Is AIDS considered a viral or bacterial infection? } & \multirow{2}{*}{ Viral } & Count & 209 & 136 & 345 \\
\hline & & $\%$ within group & $77.1 \%$ & $81.0 \%$ & $78.6 \%$ \\
\hline & \multirow{2}{*}{ Bacterial } & Count & 62 & 32 & 94 \\
\hline & & $\%$ within group & $22.9 \%$ & $19.0 \%$ & $21.4 \%$ \\
\hline \multirow{2}{*}{\multicolumn{2}{|c|}{ Total }} & Count & 271 & 168 & 439 \\
\hline & & $\%$ within group & $100 \%$ & $100 \%$ & $100 \%$ \\
\hline \multirow{4}{*}{ Are there any vaccines that prevent HIV infection? } & \multirow{2}{*}{ Yes } & Count & 147 & 69 & 216 \\
\hline & & $\%$ within group & $54.2 \%$ & $41.1 \%$ & $49.2 \%$ \\
\hline & \multirow{2}{*}{ No } & Count & 124 & 99 & 223 \\
\hline & & $\%$ within group & $45.8 \%$ & $58.9 \%$ & $50.8 \%$ \\
\hline \multirow{2}{*}{\multicolumn{2}{|c|}{ Total }} & Count & 271 & 168 & 439 \\
\hline & & $\%$ within group & $100 \%$ & $100 \%$ & $100 \%$ \\
\hline \multirow{4}{*}{ Is there a definitive treatment for HIV? } & \multirow{2}{*}{ Yes } & Count & 48 & 34 & 82 \\
\hline & & $\%$ within group & $17.8 \%$ & $20.2 \%$ & $18.7 \%$ \\
\hline & \multirow{2}{*}{ No } & Count & 222 & 134 & 356 \\
\hline & & $\%$ within group & $82.2 \%$ & $79.8 \%$ & $81.3 \%$ \\
\hline \multirow{2}{*}{\multicolumn{2}{|c|}{ Total }} & Count & 270 & 168 & 438 \\
\hline & & $\%$ within group & $100 \%$ & $100 \%$ & $100 \%$ \\
\hline \multirow{4}{*}{$\begin{array}{l}\text { Are there any medications that prevent proliferation of the } \\
\text { virus? }\end{array}$} & \multirow{2}{*}{ Yes } & Count & 159 & 107 & 266 \\
\hline & & $\%$ within group & $58.7 \%$ & $63.7 \%$ & $60.6 \%$ \\
\hline & \multirow{2}{*}{ No } & Count & 112 & 61 & 173 \\
\hline & & $\%$ within group & $41.3 \%$ & $36.3 \%$ & $39.4 \%$ \\
\hline \multirow{2}{*}{\multicolumn{2}{|c|}{ Total }} & Count & 271 & 168 & 439 \\
\hline & & $\%$ within group & $100 \%$ & $100 \%$ & $100 \%$ \\
\hline \multirow{4}{*}{$\begin{array}{l}\text { Are there any medications that decrease the incidence of } \\
\text { transmission from a pregnant woman to her fetus? }\end{array}$} & \multirow{2}{*}{ Yes } & Count & 151 & 108 & 259 \\
\hline & & $\%$ within group & $55.7 \%$ & $64.3 \%$ & $59.0 \%$ \\
\hline & \multirow{2}{*}{ No } & Count & 120 & 60 & 180 \\
\hline & & $\%$ within group & $44.3 \%$ & $35.7 \%$ & $41.0 \%$ \\
\hline \multirow{2}{*}{\multicolumn{2}{|c|}{ Total }} & Count & 271 & 168 & 439 \\
\hline & & $\%$ within group & $100 \%$ & $100 \%$ & $100 \%$ \\
\hline \multirow{4}{*}{ Is AIDS common in Jeddah? } & \multirow{2}{*}{ yes } & Count & 126 & 90 & 216 \\
\hline & & $\%$ within group & $46.5 \%$ & $53.6 \%$ & $49.2 \%$ \\
\hline & $\mathrm{no}$ & Count & 145 & 78 & 223 \\
\hline & no & $\%$ within group & $53.5 \%$ & $46.4 \%$ & $50.8 \%$ \\
\hline Total & & Count & 271 & 168 & 439 \\
\hline Tutar & & $\%$ within group & $100 \%$ & $100 \%$ & $100 \%$ \\
\hline & vec & Count & 202 & 89 & 291 \\
\hline Are there any centers for free screening in Jeddah who & yes & $\%$ within group & $74.5 \%$ & $53.0 \%$ & $66.3 \%$ \\
\hline will keep the results secret? & & Count & 69 & 79 & 148 \\
\hline & no & $\%$ within group & $25.5 \%$ & $47.0 \%$ & $33.7 \%$ \\
\hline & & Count & 271 & 168 & 439 \\
\hline Total & & $\%$ within group & $100 \%$ & $100 \%$ & $100 \%$ \\
\hline & & Count & 106 & 60 & 166 \\
\hline Is sexual contact the only way for transmission of the & yes & $\%$ within group & $39.1 \%$ & $35.7 \%$ & $37.8 \%$ \\
\hline disease? & & Count & 165 & 108 & 273 \\
\hline & no & $\%$ within group & $60.9 \%$ & $64.3 \%$ & $62.2 \%$ \\
\hline & & Count & 271 & 168 & 439 \\
\hline Total & & $\%$ within group & $100 \%$ & $100 \%$ & $100 \%$ \\
\hline
\end{tabular}

Table 2: General knowledge about HIVIAIDS. 
Citation: Alotaibi SM, Alabbas FF, Almoshadq AF, Pacha MS, Alghamdi MK (2016) Knowledge and Perceptions of HIVIAIDS among High School Students in Jeddah, Saudi Arabia. J AIDS Clin Res 7: 595. doi:10.4172/2155-6113.1000595

Page 5 of 7

\begin{tabular}{|c|c|c|c|c|c|}
\hline QUESTION & ANS. & & SOUTH & NORTH & TOTAL \\
\hline \multirow{4}{*}{$\begin{array}{l}\text { Are condoms considered a way to reduce incidence } \\
\text { of the spread of the virus? }\end{array}$} & \multirow{2}{*}{ Yes } & Count & 211 & 128 & 339 \\
\hline & & $\%$ within group & $78.7 \%$ & $76.2 \%$ & $77.8 \%$ \\
\hline & \multirow{2}{*}{ No } & Count & 57 & 40 & 97 \\
\hline & & $\%$ within group & $21.3 \%$ & $23.8 \%$ & $22.2 \%$ \\
\hline \multirow{2}{*}{\multicolumn{2}{|c|}{ Total }} & Count & 268 & 168 & 436 \\
\hline & & $\%$ within group & $100 \%$ & $100 \%$ & $100 \%$ \\
\hline \multirow{4}{*}{$\begin{array}{l}\text { Is sterilization of shared needles considered a way to } \\
\text { reduce incidence of the spread of the virus? }\end{array}$} & \multirow{2}{*}{ yes } & Count & 226 & 136 & 362 \\
\hline & & $\%$ within group & $83.4 \%$ & $81.4 \%$ & $82.6 \%$ \\
\hline & \multirow{2}{*}{ no } & Count & 45 & 31 & 76 \\
\hline & & $\%$ within group & $16.6 \%$ & $18.6 \%$ & $17.4 \%$ \\
\hline \multirow{2}{*}{\multicolumn{2}{|c|}{ Total }} & Count & 271 & 167 & 438 \\
\hline & & $\%$ within group & $100 \%$ & $100 \%$ & $100 \%$ \\
\hline \multirow{4}{*}{$\begin{array}{l}\text { Are routine checkups considered a way to reduce } \\
\text { incidence of the virus? }\end{array}$} & \multirow{2}{*}{ yes } & Count & 243 & 139 & 382 \\
\hline & & $\%$ within group & $89.7 \%$ & $82.7 \%$ & $87.0 \%$ \\
\hline & \multirow{2}{*}{ no } & Count & 28 & 29 & 57 \\
\hline & & $\%$ within group & $10.3 \%$ & $17.3 \%$ & $13.0 \%$ \\
\hline \multirow{2}{*}{\multicolumn{2}{|c|}{ Total }} & Count & 271 & 168 & 439 \\
\hline & & $\%$ within group & $100 \%$ & $100 \%$ & $100 \%$ \\
\hline \multirow{4}{*}{$\begin{array}{l}\text { Is isolation of infected people considered a way to } \\
\text { reduce incidence of the spread of the virus? }\end{array}$} & \multirow{2}{*}{ yes } & Count & 201 & 98 & 299 \\
\hline & & $\%$ within group & $74.2 \%$ & $58.3 \%$ & $68.1 \%$ \\
\hline & \multirow{2}{*}{ no } & Count & 70 & 70 & 140 \\
\hline & & $\%$ within group & $25.8 \%$ & $41.7 \%$ & $31.9 \%$ \\
\hline \multirow{2}{*}{\multicolumn{2}{|c|}{ Total }} & Count & 271 & 168 & 439 \\
\hline & & $\%$ within group & $100 \%$ & $100 \%$ & $100 \%$ \\
\hline \multirow{4}{*}{$\begin{array}{l}\text { Is avoiding eating with infected people considered a } \\
\text { way to reduce incidence of the spread of the virus? }\end{array}$} & \multirow{2}{*}{ yes } & Count & 158 & 91 & 249 \\
\hline & & $\%$ within group & $58.3 \%$ & $54.2 \%$ & $56.7 \%$ \\
\hline & \multirow{2}{*}{ no } & Count & 113 & 77 & 190 \\
\hline & & $\%$ within group & $41.7 \%$ & $45.8 \%$ & $43.3 \%$ \\
\hline \multirow{2}{*}{\multicolumn{2}{|c|}{ Total }} & Count & 271 & 168 & 439 \\
\hline & & $\%$ within group & $100 \%$ & $100 \%$ & $100 \%$ \\
\hline \multirow{4}{*}{$\begin{array}{l}\text { Is avoiding using public bathrooms considered a way } \\
\text { to reduce incidence of the spread of the virus? }\end{array}$} & \multirow{2}{*}{ yes } & Count & 178 & 89 & 267 \\
\hline & & $\%$ within group & $65.7 \%$ & $53.0 \%$ & $60.8 \%$ \\
\hline & \multirow{2}{*}{ no } & Count & 93 & 79 & 172 \\
\hline & & $\%$ within group & $34.3 \%$ & $47.0 \%$ & $39.2 \%$ \\
\hline \multirow{2}{*}{\multicolumn{2}{|c|}{ Total }} & Count & 271 & 168 & 439 \\
\hline & & $\%$ within group & $100 \%$ & $100 \%$ & $100 \%$ \\
\hline \multirow{4}{*}{$\begin{array}{l}\text { Is limiting sexual contact to within marriage } \\
\text { considered a way to reduce incidence of the spread } \\
\text { of the virus? }\end{array}$} & & Count & 200 & 107 & 307 \\
\hline & yes & $\%$ within group & $73.8 \%$ & $63.7 \%$ & $69.9 \%$ \\
\hline & $\mathrm{n}$ & Count & 71 & 61 & 132 \\
\hline & no & $\%$ within group & $26.2 \%$ & $36.3 \%$ & $30.1 \%$ \\
\hline Totol & & Count & 271 & 168 & 439 \\
\hline Iotal & & $\%$ within group & $100 \%$ & $100 \%$ & $100 \%$ \\
\hline
\end{tabular}

Table 3: Questions about preventative measures.

respondents did not have empathetic feelings towards patients, with no significant difference between the regions, while $34.3 \%$ of those in the south group and $45.8 \%$ in the north group felt contempt for infected people, and, overall, $60.4 \%$ thought HIV patients should be isolated.

\section{Discussion}

Evidence suggests that there are very poor surveillance systems for HIV/AIDS in Saudi Arabia and a lack of data on at-risk populations $[14,15]$. This is in common with many neighboring countries on the Arabian Peninsula and in the wider MENA region, which has the third fastest growing AIDS epidemic in the world [2]. The male:female ratio of 5:1 in HIV cases in KSA may indicate underreporting of female cases [14]; thus knowledge is particularly important for girls and women.
Meanwhile, there is stigma concerning HIV and AIDS in Saudi Arabia, which extends to the medical profession [10].

A number of cross-sectional studies undertaken among general populations (i.e., those without specialist medical training) in various countries have reported on knowledge about and attitudes to HIV/ AIDS. For example, among workers in Japan [16]; students at a privately owned university in Nigeria [17]; undergraduates in Ghana [18]; secondary school students in Bangladesh [19] and China [20]; university students in Ethiopia [21]; and staff at a public university in Malaysia [22]. However, in general, data on HIV/AIDS from the MENA region is considered scarce $[15,23]$. A review of culture and HIV in the region concluded that there is a need for more academic engagement and political commitment [24]. 


\begin{tabular}{|c|c|c|c|c|c|}
\hline QUESTION & ANS. & & SOUTH & NORTH & TOTAL \\
\hline \multirow{4}{*}{$\begin{array}{l}\text { Do you feel shy asking a patient about the mode of their } \\
\text { HIV infection? }\end{array}$} & \multirow{2}{*}{ yes } & Count & 161 & 109 & 270 \\
\hline & & $\%$ within group & $59.4 \%$ & $64.9 \%$ & $61.5 \%$ \\
\hline & \multirow{2}{*}{ no } & Count & 110 & 59 & 169 \\
\hline & & $\%$ within group & $40.6 \%$ & $35.1 \%$ & $38.5 \%$ \\
\hline \multirow{2}{*}{\multicolumn{2}{|c|}{ Total }} & Count & 271 & 168 & 439 \\
\hline & & $\%$ within group & $100 \%$ & $100 \%$ & $100 \%$ \\
\hline \multirow{4}{*}{$\begin{array}{l}\text { Do you have empathetic feelings toward infected } \\
\text { patients? }\end{array}$} & \multirow{2}{*}{ yes } & Count & 213 & 125 & 338 \\
\hline & & $\%$ within group & $78.6 \%$ & $74.4 \%$ & $77.0 \%$ \\
\hline & \multirow{2}{*}{ no } & Count & 58 & 43 & 101 \\
\hline & & $\%$ within group & $21.4 \%$ & $25.6 \%$ & $23.0 \%$ \\
\hline \multirow{2}{*}{\multicolumn{2}{|c|}{ Total }} & Count & 271 & 168 & 439 \\
\hline & & $\%$ within group & $100 \%$ & $100 \%$ & $100 \%$ \\
\hline \multirow{4}{*}{ Do you have contempt for the infected person? } & \multirow{2}{*}{ yes } & Count & 93 & 77 & 170 \\
\hline & & $\%$ within group & $34.3 \%$ & $45.8 \%$ & $38.7 \%$ \\
\hline & \multirow{2}{*}{ no } & Count & 178 & 91 & 269 \\
\hline & & $\%$ within group & $65.7 \%$ & $54.2 \%$ & $61.3 \%$ \\
\hline \multirow{2}{*}{\multicolumn{2}{|c|}{ Total }} & Count & 271 & 168 & 439 \\
\hline & & $\%$ within group & $100 \%$ & $100 \%$ & $100 \%$ \\
\hline \multirow{4}{*}{$\begin{array}{l}\text { Do you think it is important to isolate the infected } \\
\text { patient? }\end{array}$} & \multirow{2}{*}{ yes } & Count & 168 & 97 & 265 \\
\hline & & $\%$ within group & $62.0 \%$ & $57.7 \%$ & $60.4 \%$ \\
\hline & \multirow{2}{*}{ no } & Count & 103 & 71 & 174 \\
\hline & & $\%$ within group & $38.0 \%$ & $42.3 \%$ & $39.6 \%$ \\
\hline \multirow{2}{*}{\multicolumn{2}{|c|}{ Total }} & Count & 271 & 168 & 439 \\
\hline & & $\%$ within group & $100 \%$ & $100 \%$ & $100 \%$ \\
\hline \multirow{4}{*}{ Do you think infected people must remain in their home? } & \multirow{2}{*}{ yes } & Count & 153 & 86 & 239 \\
\hline & & $\%$ within group & $56.5 \%$ & $51.2 \%$ & $54.4 \%$ \\
\hline & \multirow{2}{*}{ no } & Count & 118 & 82 & 200 \\
\hline & & $\%$ within group & $43.5 \%$ & $48.8 \%$ & $45.6 \%$ \\
\hline \multirow{2}{*}{\multicolumn{2}{|c|}{ Total }} & Count & 271 & 168 & 439 \\
\hline & & $\%$ within group & $100 \%$ & $100 \%$ & $100 \%$ \\
\hline \multirow{4}{*}{ Do you think this research topic is important? } & \multirow{2}{*}{ yes } & Count & 252 & 142 & 394 \\
\hline & & $\%$ within group & $93.0 \%$ & $84.5 \%$ & $89.7 \%$ \\
\hline & \multirow{2}{*}{ no } & Count & 19 & 26 & 45 \\
\hline & & $\%$ within group & $7.0 \%$ & $15.5 \%$ & $10.3 \%$ \\
\hline \multirow{2}{*}{\multicolumn{2}{|c|}{ Total }} & Count & 271 & 168 & 439 \\
\hline & & $\%$ within group & $100 \%$ & $100 \%$ & $100 \%$ \\
\hline
\end{tabular}

Table 4: Attitudes toward infected patients.

Decline in HIV in Thailand and Uganda was ascribed to education and support of young people [25]. Accurate knowledge is crucial to successfully protecting oneself against HIV, while lack of knowledge concerning transmission routes and fear of knowing one's HIV status lead to failure to get tested. Meanwhile, baseline studies of knowledge are important to highlight present deficiencies in awareness and to track the progress of any public health education or policy measures taken in the future. The present survey of high school students in the city of Jeddah highlights a number of areas of concern. For example, among those surveyed, $54 \%$ think kissing is a means of transmission, while $50 \%$ think mosquito bites are. Meanwhile, $49 \%$ think an HIV vaccine is available. Many (38\%) answered that sexual contact is the only means of HIV transmission. There was significant uncertainty with respect to the relationships between pregnancy or breast feeding and HIV transmission to a child. These outcomes highlight a need for greater education in at least some aspects of HIV. However, some knowledge is clearly well established in the Jeddah students; for example, $93 \%$ and $88.2 \%$ of survey participants knew that sexual contact and sharing needles, respectively, are means of transmission, while $78 \%$ and $87 \%$ respectively knew that condom use and medical checkups are means to reduce transmission. Nearly $90 \%$ considered that research into HIV/ AIDS and attitudes towards it are important.

Our data also indicate substantial stigma associated with HIV/AIDS among the study group in Jeddah. Significant minorities think that shaking hands, sharing food and using public bathrooms are means of HIV transmission; $61 \%$ think avoiding using public bathrooms reduces the spread of the virus. Sixty percent think that isolating infected people is important; $39 \%$ feel contempt for infected people. Meanwhile, $49 \%$ think HIV/AIDS is common in Jeddah. Data are consistent with another study of Saudi teenagers [11], which reported, "some misconceptions about HIV transmission, intolerant attitude, stigma and discrimination toward HIV, which need to be addressed", and with studies of illegal residents of Saudi Arabia [10] and young people in Yemen [12]. In general, the better educated and more prosperous northern group in our study had slightly better awareness of HIV transmission routes and means of prevention than their southern counterparts, but also demonstrated higher stigma towards patients (in particular, contempt for an infected person, $45.8 \%$ vs. $34.3 \%$ ).

Stigma and discrimination have been described as the most 
Citation: Alotaibi SM, Alabbas FF, Almoshadq AF, Pacha MS, Alghamdi MK (2016) Knowledge and Perceptions of HIVIAIDS among High School Students in Jeddah, Saudi Arabia. J AIDS Clin Res 7: 595. doi:10.4172/2155-6113.1000595

important barriers to HIV treatment and prevention programs $[16,26]$. Fear of stigma has been shown to lead to a reduction in preventative behaviors (UNICEF, 2002). Studies, for example in Japan, have shown that knowledge neutralizes negative attitudes to HIV [16], while in China [20], educational intervention produced a significant increase in knowledge of and positive attitudes to HIV/AIDS. It has been shown that knowledge does not predict behavioral change where stigma is a factor, but knowledge is a prerequisite for change [27]. Again, our findings highlight the need for and desirability of formal education on HIV related topics in schools.

Schools are key players in HIV/AIDS education - both textbooks and teachers [19,22]. The mass media is also important; in Bangladesh, China and Turkey $[20,19,28]$, watching TV was found to be the best predictor of knowledge about HIV. In a recent brief report on knowledge of adolescents in eastern Saudi Arabia, 39.2\% reported that their major source of information on HIV was the media (11); in Iraq, the equivalent figure was around two-thirds [9]. The internet is a crucial resource in HIV/AIDS education (e.g. as found in Kenya and Brazil $[18,20,29]$. Such considerations are particularly relevant where information may not be available at home because of cultural conservatism (for example religious or traditional beliefs, strongly held in Saudi Arabia) and/or lack of knowledge $[17,18]$.

\section{Limitations of this Study}

This was a cross-sectional study with all the inherent limitations that implies. The sample size was relatively small $(n=438)$ and drawn from a narrow age group in a single city. The north sample group was concentrated in two schools. Jeddah may not be demographically representative of Saudi Arabia as a whole. It would be interesting to compare the results obtained here for young Saudi residents with the knowledge and opinions of older people to assess any generational shifts in awareness and attitude. Of note is that the north group contained fewer non-Saudi nationals $(9.5 \%, \mathrm{n}=15)$ than the south group $(19.6 \%$, $\mathrm{n}=53$ ); given the considerably higher prevalence of HIV among nonSaudi nationals in Saudi Arabia than among nationals, this could have some influence on the results in this study.

\section{Conclusion}

This research provides data from a country (Saudi Arabia) and region (MENA) where recent data on attitudes to and knowledge of HIV/AIDS are sparse. The study provides a benchmark for future research and a basis for discussions of public policy towards HIV awareness and education in Saudi Arabia.

\section{Acknowledgement}

Special thanks to Ms. Azza Fadhl Alsuriaihi for her great efforts in distributing our questionnaire among her students.

Special thanks to Ms. Huda Al-Otaibi for her great efforts in distributing our questionnaire among her students.

\section{References}

1. World Health Organization (2015) Global summary of the AIDS epidemic.

2. Kamarulzaman $A(2013)$ Fighting the HIV epidemic in the Islamic world. Lancet 381: 2058-2060.

3. Arab News (2013) Kingdom defeating HIV.

4. Saudi Ministry of Health (2014) Closing the gap in HIV prevention and treatment.

5. CIA (2011) World Factbook.

6. World Bank (2002) Education and HIVIAIDS a window of hope.

7. Centers for Disease Control (2016) Basic statistics.
8. Memish ZA, Filemban SM, Bamgboyel A, Al Hakeem RF, Elrashied SM, et al. (2015) Knowledge and attitudes of doctors toward people living with HIVIAIDS in Saudi Arabia. J Acquir Immune Defic Syndr 69: 61-67.

9. Othman SM (2014) Knowledge about HIVIAIDS among high school students in Erbil city/lraq. Glob J Health Sci 7: 16-23.

10. Memish ZA, Filemban SM, Kasule SN, Al-Tawfiq JA (2015) Knowledge and attitudes about HIVIAIDS in illegal residents in the Kingdom of Saudi Arabia. J Glob Infect Dis 7: 103-107.

11. Bokhamseen A, Shammari BA, Alsaai M (2015) Knowledge and attitude among adolescents towards HIVIAIDS. Bahrain Med Bull 37: 214.

12. Al-Serouri AW, Anaam M, Al-Iryani B, Al Deram A, Ramaroson S (2010) AIDS awareness and attitudes among Yemeni young people living in high-risk areas. East Med Health J 16: 242-250.

13. Badahdah A (2005) Saudi attitudes towards people living with HIVIAIDS. Int J STD AIDS 16: 837-838.

14. Bozicevic I, Riedner G, Calleja JM (2013) HIV surveillance in MENA: Recent developments and results. Sex Transm Infect 89 Suppl 3: iii11-16.

15. Mumtaz GR, Riedner G, Abu-Raddad LJ (2014) The emerging face of the HIV epidemic in the Middle East and North Africa. Curr Opin HIV AIDS 9: 183-191.

16. Wang G, Wada K, Hoshi K, Sasaki N, Ezoe S, et al. (2013) Association of knowledge of HIV and other factors with individuals' attitudes towards HIV infection: A national cross-sectional survey among the Japanese non-medical working population. PLoS One 8: e68495.

17. Abiodun O, Sotunsa J, Ani F, Jaiyesimi E (2014) Knowledge of HIVIAIDS and predictors of uptake of HIV counseling and testing among undergraduate students of a privately owned university in Nigeria. BMC Res Notes 7: 639.

18. Oppong Asante K, Oti-Boadi M (2013) HIVIAIDS knowledge among undergraduate university students: Implications for health and education programs in Ghana. Afr Health Sci 13: 270-277.

19. Huda N, Amanullah A (2013) HIV-AIDS related knowledge among secondary school students in Bangladesh: A cross-sectional study. Adv Inf Dis 3: 274-280.

20. Gao X, Wu Y, Zhang Y, Zhang N, Tang J, et al. (2012) Effectiveness of schoolbased education on HIVIAIDS knowledge, attitude and behavior among secondary school students in Wuhan, China. PLoS One 7: e44881.

21. Mulu W, Abrea B, Yimer M (2014) Knowledge, attitude and practices on HIV/ AIDS among students of Bahir Dar University. Sci J Public Health 2: 78-86.

22. Tee Y, Huang M (2009) Knowledge of HIVIAIDS and attitudes towards people living with HIV among the general staff of a public university in Malaysia. SAHARA J 6: 179-187.

23. Boneberger A, Rückinger S, Guthold R, Kann L, Riley L (2012) HIVIAIDS related knowledge among school-going adolescents from the Middle East and North Africa. Sex Health 9: 196-198.

24. Alkaiyat A, Weiss MG (2013) HIV in the Middle East and North Africa: Priority, culture and control. Int J Public Health 58: 927-937.

25. UNICEF (2002) Young People and HIVIAIDS: opportunity in crisis.

26. Lieber E, Li L, Wu Z, Rotheram-Borus MJ, Guan J, et al. (2006) HIV/STD stigmatization fears as health-seeking barriers in China. AIDS Behav 10: 463471.

27. Fawole IO, Asuzu MC, Oduntan SO, Brieger WR (1999) A school-based AIDS education programme for secondary school students in Nigeria: A review of effectiveness. Health Educ Res 14: 675-683.

28. Ungan M, Yaman H (2003) AIDS knowledge and educational needs of technical university students in Turkey. Patient Educ Couns 51: 163-167.

29. Halpern CT, Mitchell EMH, Farhat T, Bardsley P (2008) Effectiveness of webbased education on Kenyan and Brazilian adolescents' knowledge about HIV/ AIDS, abortion law and emergency contraception: Findings from TeenWeb. Soc Sci Med 67: 628-637. 